E3S Web of Conferences 1, 06003 (2013)

DOI: $10.1051 / \mathrm{e} 3$ sconf $/ 20130106003$

C) Owned by the authors, published by EDP Sciences, 2013

\title{
Redox oscillation affecting mercury mobility from highly contaminated coastal sediments: a mesocosm incubation experiment
}

\author{
A. Emili ${ }^{1}$, L. Carrasco ${ }^{2}$, A. Acquavita ${ }^{3}$ and S. Covelli ${ }^{1}$ \\ ${ }^{1}$ Dipartimento di Matematica \& Geoscienze, Università di Trieste, Via Weiss 2, 34128 Trieste (Italy), \\ andemili@gmail.com, covelli@units.it \\ ${ }^{2}$ Environmental Chemistry Department, IDAEA-CSIC, Jordi Girona 18-26, 08034 Barcelona, (Spain), \\ carrascocabreraluis@gmail.com \\ ${ }^{3}$ Osservatorio Alto Adriatico, Agenzia Regionale per la Protezione dell'Ambiente del Friuli Venezia Giulia \\ (ARPA-FVG), Via Cairoli 14, 33057, Palmanova (Italy), acquavitaa@arpa.fvg.it
}

\begin{abstract}
Mercury ( $\mathrm{Hg}$ ) mobility at the sediment-water interface was investigated during a laboratory incubation experiment on highly contaminated sediments (up to $23 \mu \mathrm{g} \mathrm{g}^{-1}$ ) of the Gulf of Trieste. Undisturbed sediment was collected in front of the Isonzo River mouth, which inflows Hg-rich suspended material originating from the Idrija (NW Slovenia) mining district. Since hypoxic and anoxic conditions at the bottom are frequently observed, a redox oscillation was simulated in the laboratory at in situ temperature, using a dark flux chamber. Temporal variations of several parameters were monitored simultaneously: dissolved $\mathrm{Hg}$ and methylmercury $(\mathrm{MeHg}), \mathrm{O}_{2}, \mathrm{NH}_{4}{ }^{+}, \mathrm{NO}_{3}{ }^{-}+\mathrm{NO}_{2}{ }^{-}, \mathrm{PO}_{4}{ }^{3-}, \mathrm{H}_{2} \mathrm{~S}$, dissolved $\mathrm{Fe}$ and $\mathrm{Mn}$, dissolved inorganic and organic carbon (DIC and DOC). Benthic fluxes of $\mathrm{Hg}$ and $\mathrm{MeHg}$ were higher under anoxic conditions while re-oxygenation caused concentrations of $\mathrm{MeHg}$ and $\mathrm{Hg}$ to rapidly drop, probably due to re-adsorption onto $\mathrm{Fe} / \mathrm{Mn}$ oxyhydroxides and enhanced demethylation. Hence, during anoxic events, sediments of the Gulf of Trieste may be considered as an important source of dissolved $\mathrm{Hg}$ species for the water column. However, re-oxygenation of the bottom compartment mitigates $\mathrm{Hg}$ and $\mathrm{MeHg}$ release from the sediment, thus acting as a natural "defence" from possible interaction between the metal and the aquatic organisms.
\end{abstract}

Key words: Mercury, sediments, benthic chamber, incubation

\section{Introduction}

The Gulf of Trieste (northern Adriatic Sea) has been affected by mercury $(\mathrm{Hg})$ inputs from the Isonzo River, the largest contributor of this metal into the northern Adriatic Sea since the 16th century, due to its transport of cinnabar (HgS) rich tailings from the Idrija (Slovenia) mining district (Covelli et al., 2001). Mercury is still delivered to the nearby Gulf of Trieste (Horvat et al., 1999; Faganeli et al., 2003; Covelli et al., 2006, 2007), where bottom sediments show $\mathrm{Hg}$ concentrations ranging from 0.10 to $23.3 \mu \mathrm{g} \mathrm{g}^{-1}$ against an estimated natural background of $0.13 \mu \mathrm{g} \mathrm{g}^{-1}$. Hypoxic/anoxic conditions at the sediment - water interface (SWI) have been observed in the Gulf of Trieste, as a consequence of high loadings of nutrients and organic matter and strong late summer water stratification (Faganeli et al., 1991). Under such environmental conditions, sediments could act as a significant source of in situ $\mathrm{Hg}$ methylated species
(Fitzgerald et al., 2007; Merritt and Amirbahman, 2009). By means of an incubated benthic chamber it is possible to observe, under controlled laboratory conditions, the effects of $\mathrm{O}_{2}$ depletion on the biogeochemical behavior of the benthic compartment (Ogrinc and Faganeli, 2006; Covelli et al., 2008; Emili et al., 2011).

The aim of this study was to evaluate $\mathrm{Hg}$ and $\mathrm{MeHg}$ cycling at the SWI in the Gulf of Trieste in case of anoxic events, simulating an oxic/anoxic transition in a dark incubated benthic chamber, at in situ temperature. To this purpose, a volume of undisturbed sediment was sampled from an experimental site located in front of the Isonzo River mouth (Fig. 1), where an elevated $\mathrm{Hg}$ content was expected, on the basis of previous investigations (Covelli et al., 2001). In addition to $\mathrm{Hg}$ species, water samples were also analyzed for $\mathrm{H}_{2} \mathrm{~S}$, nutrients ( $\mathrm{N}$ and $\mathrm{P}), \mathrm{Fe}$ and $\mathrm{Mn}$, dissolved inorganic and organic C (DIC and DOC), to better understand the redox processes occurring in the incubated system. 


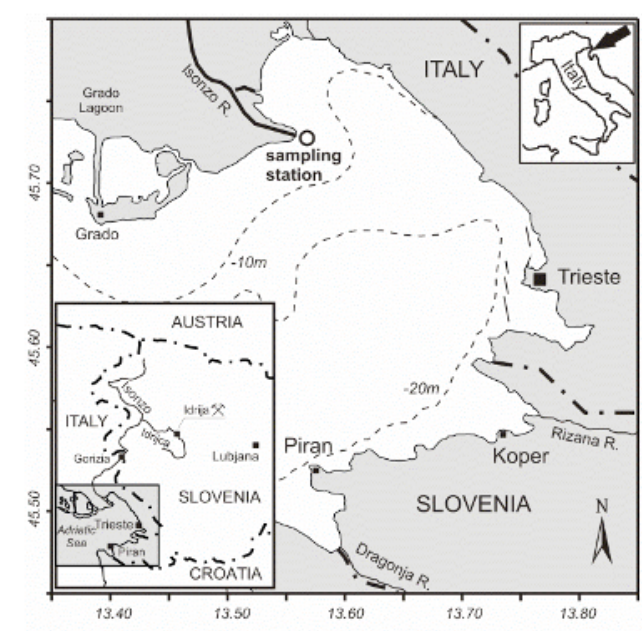

Fig. 1. Location of the sampling station (Gulf of Trieste, Northern Adriatic Sea, Italy).

\section{Materials and Methods}

Bottom sediment and the overlying water were collected by a SCUBA diver in June 2010, using a cylindrical Plexiglas chamber as a sampler $(\mathrm{h}=25 \mathrm{~cm}$, i.d. $=24 \mathrm{~cm})$. The chamber was carefully transported to the laboratory where the overlying water was replaced by in situ collected bottom seawater. The chamber was sealed and placed in a dark room at in situ temperature $\left(24^{\circ} \mathrm{C}\right)$ for incubation (Fig. 2).

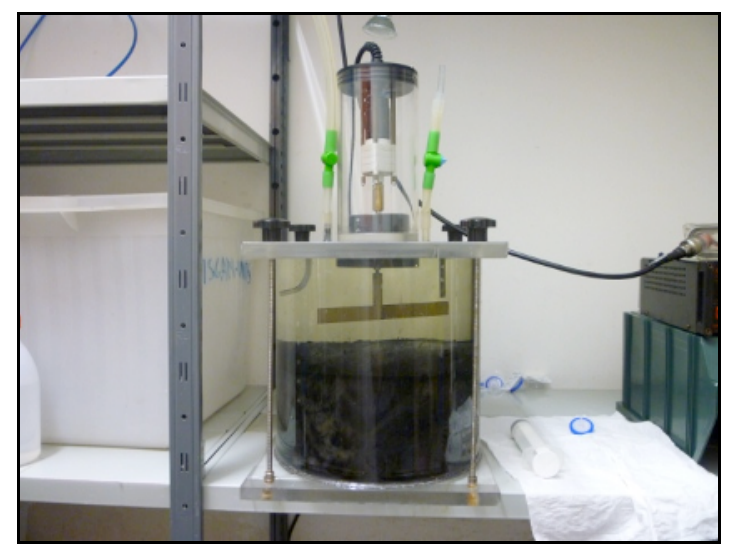

Fig. 2. The incubated benthic chamber with its stirring mechanism.

After 27 days, the system was re-oxygenated by opening the chamber and leaving the water surface in contact with the atmosphere for 7 days. Throughout the incubation experiment, water samples were periodically collected from the chamber using a plastic syringe and the withdrawn volume of water was compensated by in situ collected bottom seawater. Prior to each sampling, the system was homogenized for $15 \mathrm{~min}$ by means of a magnetic stirrer.

Dissolved $\mathrm{O}_{2}$ was determined by the Winkler method (Grasshoff et al., 1983) using an automated titration system (Mettler Toledo DL 21). Determination of $\mathrm{H}_{2} \mathrm{~S}$ was performed spectrophotometrically after trapping with $\mathrm{Zn}$ acetate (Grasshoff et al., 1983). Other parameters in the dissolved phase were determined on samples filtered through a Millipore Millex HA $0.45 \mu \mathrm{m}$ filter. DIC and DOC determinations were performed using a Shimadzu TOC 5000A analyzer. Dissolved Fe and $\mathrm{Mn}$ were determined by GFAAS (Perkin Elmer 5100PC) using $\mathrm{Mg}\left(\mathrm{NO}_{3}\right)_{2}$ as a matrix modifier. Nutrients were determined according to Grasshoff et al. (1983) using a continuous flow segmented system (Bran-Luebbe AAQuattro).

Total $\mathrm{Hg}$ in the solid phase was determined by CVAAS (Perkin Elmer AAnalyst 100-FIAS) after a total decomposition of the sample with a mixture of $\mathrm{HF}+$ aqua regia in a closed microwave system (Milestone MLS 1200). Total dissolved $\mathrm{Hg}$ determination was performed according to Horvat et al. (1991): after exposure to $\mathrm{UV}$ light and oxidation with $\mathrm{BrCl}(0.5$ $\mathrm{mL} / 100 \mathrm{~mL}$ sample), pre-reduction $\left(\mathrm{NH}_{2} \mathrm{OH} \cdot \mathrm{HCl}, 0.25\right.$ $\mathrm{mL} 30 \%$ ) was followed by reduction with $\mathrm{SnCl}_{2}$ and $\mathrm{Au}$ trapping. Analyses were performed by a Brooks Rand CVAFS. MeHg analyses were conducted according to Horvat et al. (1993a,b) and Liang et al. (1994a,b). After distillation, water samples were ethylated $(\mathrm{pH} \mathrm{4.6,100}$ $\mu \mathrm{L}$ of acetate buffer, $50 \mu \mathrm{L} \mathrm{NaBEt}_{4} 1 \%$ ), recollected on Tenax traps at room temperature $\left(t=15 \mathrm{~min}, \mathrm{Hg}\right.$-free $\left.\mathrm{N}_{2}\right)$, and thermally desorbed $\left(\mathrm{T}=180^{\circ} \mathrm{C}\right)$. Separation of the ethylated species was performed on a GC column. Mercury species were converted to $\mathrm{Hg}^{0}$ by pyrolysis at $600^{\circ} \mathrm{C}$ and measured by CVAFS. Recovery of $\mathrm{MeHg}$ was estimated in each batch of analyses by spiking the samples with a known amount of $\mathrm{MeHg}$ in aqueous solution prior to distillation and analysis.

\section{Results and Discussion}

The average total $\mathrm{Hg}$ content in the surficial sediment (0-3.5 $\mathrm{cm})$ was about $12 \mu \mathrm{g} \mathrm{g}^{-1}$, compared to the $>30 \mu \mathrm{g}$ $\mathrm{g}^{-1}$ maximum concentration reported in Hines et al. (2006).

An $\mathrm{O}_{2}$ concentration $<32 \mu \mathrm{mol} \mathrm{L}{ }^{-1}\left(1 \mathrm{mg} \mathrm{L}^{-1}\right)$ was considered the limit for the hypoxic/anoxic transition. After 7 days of incubation, $\mathrm{O}_{2}$ in the benthic chamber was no more detectable (Fig. 3). Oxygen was resupplied to the system by opening the benthic chamber after 27 days of incubation. As a consequence, $\mathrm{O}_{2}$ concentration quickly rose to $142 \mu \mathrm{mol} \mathrm{L} \mathrm{L}^{-1}$, reaching a maximum of $291 \mu \mathrm{mol} \mathrm{L}{ }^{-1}$ which was similar to the concentration values observed at the begininning of the experiment.

During the oxic/anoxic transition, early diagenetic processes of organic matter consumption caused the remineralization of nutrients and the release of $\mathrm{Fe} / \mathrm{Mn}$ and $\mathrm{Hg}$ species from the sediment.

$\mathrm{MeHg}$ was almost undetectable $\left(0.03 \mathrm{ng} \mathrm{L}^{-1}\right)$ at the beginning of the experiment, and it rose to a maximum of $39 \mathrm{ng} \mathrm{L}^{-1}$ during the early stages of anoxia (Fig. 3). After 20 days of incubation, still under anoxic conditions and before reoxygenation, $\mathrm{MeHg}$ decreased to about $22 \mathrm{ng} \mathrm{L}^{-1}$. After reoxygenation, $\mathrm{MeHg}$ quickly disappeared from the water column, decreasing to $0.3 \mathrm{ng} \mathrm{L}^{-1}$ at the end of the experiment. $\mathrm{H}_{2} \mathrm{~S}$ paralleled $\mathrm{MeHg}$ behavior, rising from $0.36 \mu \mathrm{mol} \mathrm{L}^{-1}$ at $\mathrm{t}=0$ to a maximum of $75 \mu \mathrm{mol} \mathrm{L} \mathrm{L}^{-1}$ after 
20 days of incubation. After that, $\mathrm{H}_{2} \mathrm{~S}$ concentration decreased, reaching undetectable levels after the reoxygenation of the system. Manganese was released from the sediment already at the beginning of the experiment, when $\mathrm{O}_{2}$ depletion was slowly ongoing. The quick drop in concentration following reoxygenation suggests that Mn oxides were formed, possibly removing from solution other solutes (like $\mathrm{MeHg}$ ) by coprecipitation. The observed behavior of $\mathrm{H}_{2} \mathrm{~S}$ and $\mathrm{MeHg}$ suggests that $\mathrm{Hg}$ methylation by sulfate-reducing bacteria (Compeau and Bartha, 1985) was active in the incubated sediment and that the hypoxic/anoxic conditions induced in the system favored methylation processes, as long as
$\mathrm{H}_{2} \mathrm{~S}$ concentration in the water column was below 80 $\mu \mathrm{mol} \mathrm{L}{ }^{-1}$. After the optimum in sulfate reduction and the corresponding methylation processes, the system buffered both $\mathrm{H}_{2} \mathrm{~S}$ and $\mathrm{MeHg}$ concentrations and the species were removed from solution, possibly by precipitation of insoluble sulfides (Benoit et al., 1999).

The sudden disappearance of $\mathrm{H}_{2} \mathrm{~S}$ and $\mathrm{MeHg}$ from the water column following the system reoxygenation suggests that $\mathrm{Hg}$ methylation in the incubated sediment is strongly dependant on the redox conditions of the system. Oxygen depletion triggers $\mathrm{Hg}$ methylation and $\mathrm{MeHg}$ is removed from the water column when oxic conditions are restored.
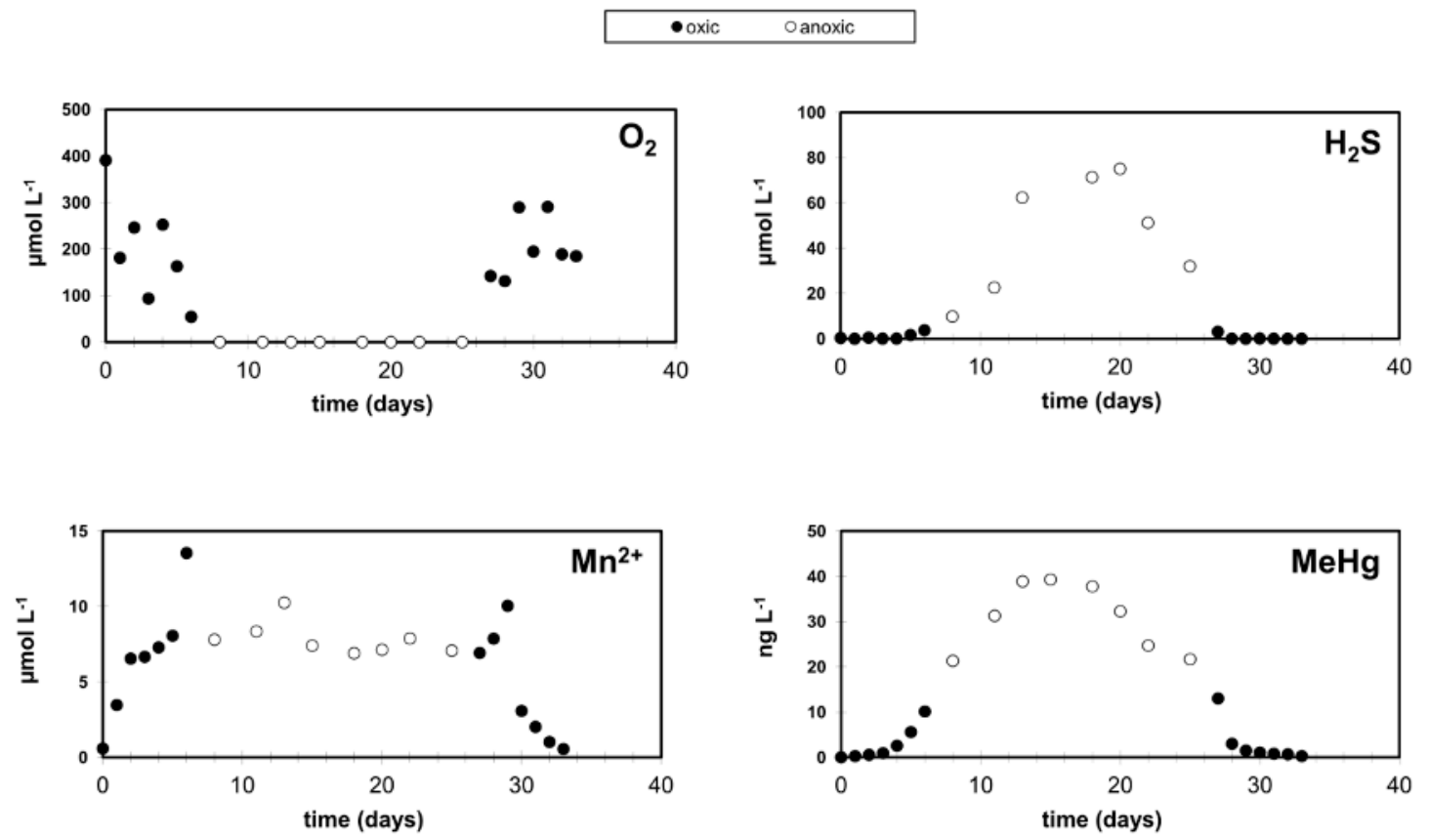

Fig. 3. Variation of solutes $\left(\mathrm{O}_{2}, \mathrm{H}_{2} \mathrm{~S}, \mathrm{Mn}^{2+}\right.$, MeHg) concentration with incubation time. Black dots represent the oxic phase of the experiment, white dots represent the anoxic phase.

\section{Conclusion}

Hypoxic and anoxic conditions play a significant role in the remobilization of $\mathrm{Hg}$ from sediments at the Isonzo River mouth in the Gulf of Trieste. The increasing sulfide concentration in the benthic chamber is well correlated with the parallel increase in $\mathrm{MeHg}$, in accordance with the hypothesis of $\mathrm{Hg}$ methylation being related to $\mathrm{SO}_{4}{ }^{2-}$ reduction in anoxic sediments. The observed effects of sediment reoxygenation on the solutes concentrations suggest that reversion to oxic conditions removes $\mathrm{Hg}$ species from the water column, most probably through precipitation and coprecipitation with $\mathrm{Fe}$ and $\mathrm{Mn}$ oxyhydroxides. These findings are useful to understand $\mathrm{Hg}$ cycling at the SWI during hypoxic/anoxic events and the fate of $\mathrm{Hg}$ species following the restoration of the normal oxygenation conditions of the bottom waters.

\section{Acknowledgements}

The authors would like to thank Michele Giani and
Cinzia De Vittor of OGS-BIO Trieste for $\mathrm{H}_{2} \mathrm{~S}$ and DIC analyses. L.C. kindly acknowledges a predoctoral fellow-ship (programa I3P) from the Consejo Superior de Investigaciones Científicas (CSIC, Spain).

\section{References}

Benoit JM, Gilmour CC, Mason RP, Heyes A. Sulfide Controls on Mercury Speciation and Bioavailability to Methylating Bacteria in Sediment Pore Waters. Environ Sci Technol 1999; 33:951-957.

Compeau G, Bartha R. Sulphate-reducing bacteria: principal methylators of mercury in anoxic estuarine sediment. Appl Environ Microbiol 1985; 50:498-502.

Covelli S, Faganeli J, Horvat M, Brambati A. Mercury contamination of coastal sediments as the result of long-term cinnabar activity (Gulf of Trieste, northern Adriatic Sea). Appl Geochem 2001; 16:541-558.

Covelli S, Piani R, Kotnik J, Horvat M, Faganeli J, Brambati A. Behaviour of $\mathrm{Hg}$ species in a 
microtidal deltaic system: The Isonzo River mouth (northern Adriatic Sea). Sci Total Environ 2006; 368:210-223.

Covelli S, Piani R, Acquavita A, Predonzani S, Faganeli J. Transport and dispersion of particulate $\mathrm{Hg}$ associated to a river plume in coastal Northern Adriatic environments. Mar Pollut Bull 2007; 55:436-450.

Covelli S, Faganeli J, De Vittor C, Predonzani S, Acquavita A, Horvat M. Benthic fluxes of mercury species in a lagoon environment (Grado lagoon, Northern Adriatic Sea, Italy). Appl Geochem 2008; 23:529-546.

Emili A, Koron N, Covelli S, Faganeli J, Acquavita A, Predonzani S, De Vittor C. Does anoxia affect mercury cycling at the sediment-water interface in the Gulf of Trieste (northern Adriatic Sea)? Incubation experiments using benthic flux chambers. Appl Geochem 2011; 26:194-204.

Faganeli J, Pezdic J, Ogorelec B, Herndl GJ, Dolenec T. The role of sedimentary biogeochemistry in the formation of hypoxia in shallow coastal waters (Gulf of Trieste, Northern Adriatic). In: Tyson, R.V., Pearson, T.H. (Eds.), Modern and Ancient Continental Shelf Anoxia. Geological Society, London, Spec 1991. Publ. 58, pp. 107-117.

Faganeli J, Horvat M, Covelli S, Fajon V, Logar M, Lipej L, Cermelj B. Mercury and methylmercury in the Gulf of Trieste (northern Adriatic Sea). Sci Total Environ 2003; 304:315-326.

Fitzgerald WF, Lamborg $\mathrm{CH}$, Hammerschmidt CR. Marine biogeochemical cycling of mercury. Chem Rev 2007; 107:641-662.

Grasshoff K, Ehrhardt M, Kremling K. Methods of Seawater Analysis, $2^{\text {nd }}$ ed. Verlag Chemie, Weinheim, 1983.

Hines ME, Faganeli J, Adatto I, Horvat M. Microbial Mercury transformations in marine, estuarine and freshwater sediment downstream of the Idrija Mercury Mine, Slovenia. Appl Geochem 2006; 21:1924-1939.

Horvat M, Miklavčič V, Pihlar B. Determination of total mercury in coal fly ash by gold amalgamation cold vapour atomic absorption spectrometry. Anal Chim Acta 1991; 243:71-79.

Horvat M, Bloom NS, Liang L. Comparison of distillation with other current isolation methods for the determination of methyl mercury compounds in low level environmental samples: Part I. Sediments. Anal Chim Acta 1993a; 281:135-152.

Horvat M, Bloom NS, Liang L. Comparison of distillation with other current isolation methods for the determination of methyl mercury compounds in low level environmental samples: Part II. Water. Anal Chim Acta 1993b; 282:153-168.

Horvat M, Covelli S, Faganeli J, Logar M, Mandic V, Rajar R, Sirca A, Zagar D. Mercury in contaminated coastal environments; a case study: the Gulf of Trieste. Sci Total Environ 1999; 237/238:43-56.

Liang L, Bloom NS, Horvat M. Simultaneous determination of mercury speciation in biological materials by GC/CVAFS after ethylation and room temperature precollection. Clin Chem 1994a; 40:602-607.

Liang L, Horvat M, Bloom NS. An improved method for speciation of mercury by aqueous phase ethylation, room temperature precollection, GC separation and CV AFS detection. Talanta 1994b; 41:371-379.

Merritt KA, Amirbahman A. Mercury methylation dynamics in estuarine and coastal marine environments - a critical review. Earth Sci Rev 2009; 96:54-66.

Ogrinc N, Faganeli J. Phosphorus regeneration and burial in near-shore marine sediments (the Gulf of Trieste, northern Adriatic Sea). Estuar Coast Shelf Sci 2006; 67:579-588. 